\title{
Oor die toelating tot die Nagmaal
}

\author{
A D Pont \\ Emeritus-professor: Departement Kerkgeskiedenis en Kerkreg \\ Universiteit van Pretoria
}

\begin{abstract}
On being admitted to the Lord's Supper

In this study the matter of the invitation to the Holy Supper, in particular the question of who may or should be invited, is discussed. A historical introduction precedes a discussion on the matter among Protestant churches in South Africa in light of the fact that children as young as age 6-7 are now being invited in the Dutch Reformed Church (NG Kerk), to participate in the Holy Supper. Special attention is paid to the Calvinist tradition.
\end{abstract}

\section{INLEIDING}

Dit was 'n verrassende versoek van die redakteur van $H T S$ om aan hierdie bundel waarmee prof S J Botha gehuldig word, deel te neem. Dit was verrassend in die sin dat dit my onkant gevang het om te moet besef dat my gewaardeerde opvolger in die Departement Kerkgeskiedenis nou al emeriteer. Meer faktore as net die verbygaan van die jare het natuurlik hier ook 'n rol gespeel.

In ieder geval is dit vir my 'n besondere voorreg om 'n bydrae te mag maak. Dit veral omdat my verbintenis met prof Botha terugloop na 1957 toe ek as dosent en departementshoof in die Fakulteit Teologie aangestel is. Deur al die jare het die verbintenis gegroei soos ons in die kerk op verskillende terreine saamgewerk het. Een van die interessante terreine was die werk aan die nuwe kerkorde. Daar kon ons saamwerk om heelwat van die filosofies-bepaalde, administratiewe Kerkwettradisies op te ruim om 'n baie meer Skrifbepaalde lewensorde aan die kerk voor te lê. Tiperend van ons tyd is dat die wêreldlike regulasies wat mag en aansien verleen aan bepaalde "uitvoerende funksies" in die kerk, die moeilikste was om van afskeid te neem. Selfs in die kerk wil die mens graag die hoogste' en die laaste woord spreek en sy beplanning en 
strategiee deurvoer. Danksy prof Botha se insig en leiding was dit moontlik om 'n kerkorde daar te stel wat poog om die Christokrasie in die kerk tot sy reg te laat kom.

Vanweë prof Botha se kerkregtelike belangstelling en terwyl daar in hierdie dae nogal vrae is rondom die toelating tot die Nagmaal, is hierdie histories-kerkregtelike studie onderneem. Met graagte dra ek hierdie werkstuk op aan 'n oudstudent, kollega en goeie vriend as blyk van dank vir wat hy reeds beteken en gedoen het vir kerk en volk. Daarby wil ek my waardering voeg vir alles wat ek deur die jare van hom ontvang het.

\section{OOR DIE TOELATING TOT DIE NAGMAAL IN DIE BEGIN}

Die hele saak van die toelating tot die Nagmaal het in die jongste tyd weer na vore gekom en heelwat vrae laat ontstaan. Enersyds het dit gebeur vanwee die besluit van die Algemene Sinode van die NG Kerk in 1998 om kinders vanaf 6-7 jarige ouderdom tot die Nagmaal toe te laat. Andersyds het die vraag na vore gekom of die sogenaamde oop uitnodiging na die Nagmaal (Ordinansie 5.2.2v) in die lig van hierdie NG-besluit gehandhaaf moet word. Daarom is hierdie histories-dogmatiese ondersoek onderneem om sodoende die terrein 'n bietjie te verken en om te probeer vasstel wat die voortdurende gewoonte in hierdie verband is.

Dit is so dat die toelating tot die Nagmaal nog altyd in die kerk met omsigtigheid hanteer is. In alle tye en in alle kerke is daar 'n bepaalde voorbereiding en keuring voorgeskryf wat voorafgaan aan die toelating tot die Nagmaal. In die meeste gevalle is een of ander vorm van kategese of onderrig 'n voorwaarde vir die toelating.

In die Vroez Kerk waar aanvanklik die sendingsituasie oorheers het, was die kategese 'n voorbereiding vir die doop van volwasse bekeerlinge en het die toelating tot die Nagmaal sondermeer op die doop gevolg. Interessant is dat die kandidate vir die doop en dus vir die toelating tot die Nagmaal eers na 'n driejarige kategumenaat ondersoek moes word sodat vasgestel kon word of hulle lewenstyl Christelik is. Onder 'n Christelike lewe is dan verstaan dat hulle weduwees gerespekteer het, siekes besoek het en alle goeie werke gedoen het. Indien aan hierdie toets voldoen is, is aan hulle 'n verdere opleiding in die leer van die kerk gegee sodat hulle dan gedurende die paasfeesgodsdiensoefeninge gedoop kan word (Jungman 1959:77-79). Dit is, in die bree gesien, die situasie tot aan die begin van die $4^{\mathrm{e}}$ eeu. 
Wanneer die kinderdoop geleidelik die proselietedoop of die doop van volwasse bekeerlinge vervang het, is doop en Nagmaal in die kerklike lewe van mekaar geskei. Dan word die kinderdoop as ' $t$ ware voltooi deur die konfirmasie, die toelating tot die Nagmaal. Daardie toelating of konfirmasie het in die Rooms-Katolieke Kerk 'n sakrament wat 'n character meedeel, geword. Die sakramentsteken van die konfirmasie is die heilige olie waarmee die kandidaat gesalf word. So word dit sigbaar dat die gelowige 'n deelgenoot van Christus is wat deur God met vreugde-olie gesalf is (Ps 45:18; Palmer 1954:21-22). In hierdie situasie waar die konfirmasie op die doop volg en die voorwaarde vir die toelating tot die Nagmaal is, het die kategese nog die aksent op die lewenstyl behou maar word dit aangevul deur 'n kategese wat 'n voorbereiding is vir die deelname aan die Nagmaal. Om hierdie handelswyse te motiveer word verwys na die feit dat Jesus eers die Nagmaal vir sy dissipels instel na 'n driejarige periode van opleidingdissipelskap wat hulle vir hulle toekomstaak moes bekwaam.

Vanuit die Skriftuurlike gegewens in hierdie verband kan daarop gewys word dat die Nagmaal in die Nuwe Verbond wel verstaan is as 'n analogie van die pasga van die Ou Verbond (1 Kor 5:7). Maar die Nagmaal is nie 'n herhaling van die pasga nie, maar 'n nuwe sakrament met 'n nuwe inhoud en nuwe tekens. Die Nagmaal as sakramentele maaltyd is 'n heenwysing na die kruisiging van Jesus Christus, die ewige Seun van God wat self God is. Dit is juis deur sy kruisiging dat Jesus 'n soenoffer terwille van die sonde van die mens word. Hierdie maaltyd wat geloof en begrip vra is, volgens die Vroes Kerk, net toeganklik vir mense wat daarmee instem en 'n bepaalde lewenstyl handhaaf.

Dit is duidelik: die Nagmaal is na inhoud en betekenis baie meer as die pasga van die $\mathrm{Ou}$ Verbond. Die pasga was en is 'n herhaling van daardie eerste pasga en die betekenis van daardie historiese gebeure moet aan die kinders vertel word (Eks 12:3-28). Die aksent van die pasga is dat dit ' $n$ herinneringsmaaltyd is wat teruggryp na die ou volk se uittog uit Egipte (Eks 12:14, 24-29). Dit is belangrik om daarop te let dat die opdrag om die pasga te vier van God kom (Eks 12:14) en dat die kindervraag na die betekenis van die diens nie impliseer dat die ou volk se pasga 'n kind-bepaalde fees of 'n fees terwille van die kinders was of is nie. 
Teenoor die pasga wat in herinnering roep, moet die Nagmaalboodskap geglo word en besef word dat dit die vervulling van die pasga van die Ou Verbond is. Daardie pasga het na die eerste Nagmaal sy betekenis en profetiese heenwysing vir die volk van God verloor. Daarom is dit nie vanpas om die gebruike van die pasga van die $\mathrm{Ou}$ Verbond op die Nagmaal van die Nuwe Verbond oor te dra nie. Dit het ook nie in die Vroee Kerk gebeur nie want die beeld van die Jerusalemse gemeente wat in Handelinge 2:42-47 gegee word, is nie die tekening van 'n gemeenskap wat by die herhaling van die pasga van die ou volk vasgehaak het nie. In Handelinge 2 word dit duidelik dat die Nagmaal-eucharistie heeltemal eiesoortig ten opsigte van die pasga weekliks gevier is en dat dit daar gaan om die ontmoeting-in-die-geloof met die Verlosser-Heer en die herinnering aan sy offer sodat sy volk kon uittrek uit die slawehuis van die sonde. Dit kan duidelik gestel word dat die Nuwe-Testamentiese gegewens oor die Nagmaaleucharistie nie die indruk gee dat die Nagmaal na inhoud en betekenis bepaal is deur die sosiologiese of sosialistiese behoeftes en begeertes van die volk wat na die kruisiging van Jesus staan en kyk het (Luk 23:35) nie.

In die Nuwe Testament word daar geen aanduiding gegee of die gedoopte kinders van die gelowiges Nagmaal gebruik het nie. Dit is nogal opmerklik dat in Hand 2:39 waar Petrus sê: "Want die belofte kom julle toe en julle kinders ..." in die verdere verloop van die relaas dit duidelik is dat hier slegs van volwassenes sprake is (vs 44-46). Net so is dit uit 1 Korintiêrs 11:17 duidelik dat die betoog tot volwassenes gerig is en dat die kinders nie ter sprake is nie. Dit is natuurlik nie 'n sluitende argument nie. Tog wil dit voorkom dat in die Nuwe-Testamentiese gemeentes die kinders nie aan die gemeentelike Nagmaal deelgeneem het nie. Die instelling van die Nagmaal suggereer ook nie dat kinders deel van die viering moet wees nie en dit terwyl Jesus oor die kinders tog 'n spesifieke opdrag gegee het (vgl Luk 18:16).

In die Vroee Kerk is die kinders aanvanklik nie tot die Nagmaal toegelaat voordat hulle nie, na die doop, die kategese deurloop en toegelaat is tot Nagmaal nie. Maar die praktyk dat kinders, selfs suigelinge na die Nagmaal gaan, word deur biskop Cyprianus van Kartago (oorl 258), aangedui in sy De Lapsis, 25. Daar vertel hy van 'n babadogtertjie aan wie die gekonsekreerde wyn in die tyd van die vervolgings gegee is. Bethune-Baker (1958:418) lei daaruit af dat die kinderkommunie in Noord-Afrika 'n 
algemene praktyk moes gewees het. Harnack (1909:479) sien die kinder-Nagmaal as iets wat eerder algemeen aanvaar is in die Vroee Kerk as die kinderdoop omdat geoordeel is dat die kind, net soos sy ouers, reg het op die "zauberische himmlische Speise". Hy oordeel dat die gebruik in die kerk is ook vanwee 'n stelling in kanon 13 van die Konsilie van 325 wat gestel het dat 'n algemene reel is dat 'n biskop na 'n ondersoek aan elke sterwende gelowige wat daarvoor vra, ongeag van sy moreel-sedelike toestand, die Nagmaal moet bedien. Waar die doop in die Vroee Kerk se opvatting die afwassing van die erfsonde beteken het, is die Nagmaal gesien as die uitwis van die mens se daadsonde. So kan die gedoopte wat die Nagmaal ontvang, sondeloos sterwe of dan weer sondeloos verder lewe. Dit was waarskynlik die teologiese agtergrond wat die kinderdoop en die kindernagmaal in die Vroeẽ Kerk aan mekaar gekoppel het. Dit gebeur inderdaad in die 4e eeuse Constitutiones apostolorum (8.12) waar bepaal word dat wanneer die katkisante versoek word om hulleself, net voor die bediening van die Nagmaal, uit die kerkgebou te verwyder, dat die moeders dan hulle kinders by hulle sal hou. Daardie kinders ontvang dan die Nagmaal net na die ampsdraers en net voor die gemeente opgeroep word om die Nagmaal te ontvang.

Dit bly egter moeilik om vas te stel hoe algemeen die gebruik was dat kinders en suigelinge Nagmaal kon gebruik het. Dit wil egter voorkom dat hierdie gebruik nie die toets dat dit oral, deur almal en altyd in die kerk aanvaar is, sal kan slaag nie. Dit ook omdat pous Eugenius IV in sy bul, Exultate Deo, van 22 November 1439 die suigelingkindernagmaal in die Roomse kerk verbied het (Denzinger 1957:257).

Die aanvaarding van die leer van die transsubstansiasie van die Nagmaalselemente het buitendien die suigeling-Nagmaal onmoontlik gemaak want met Trente is bepaal dat die "gewone gelowiges" slegs die brood en nie meer die wyn sal ontvang nie. Trente het in sessio xxi op 16 Julie 1562 die suigeling-Nagmaal pertinent afgewys. Allereers is, met 'n beroep op 1 Kor 11 gestel dat vereis word dat elkeen wat Nagmaal wil gebruik, homself eers moet beproef. Dit is egter 'n vraag of 'n suigeling daaraan kan voldoen. Ten tweede is geargumenteer dat die suigeling-Nagmaal die effektiewe werking van die doop in twyfel trek. Kinders wat nog nie 'n doodsonde kan begaan nie, kan tog nie 'n tweede of verdere sakrament, wat al hulle sondes vergewe, nodig hê niẹ. Die kind is immers by sy doop "skoongewas" van sowel sy erf- as daadsonde. Daarteen is 
geargumenteer dat indien alleen diegene wat hulleself kan beproef die sakrament mag ontvang, dan kan die kind mos nie gedoop word nie. Dit is egter as 'n foutiewe argument afgewys want die Skrif vra wel die selfbeproewing by die Nagmaal maar nie by die doop nie. Om nou die twee sakramente te wil "gelykskakel" is nie aanvaarbaar nie omdat die doop en die Nagmaal nie presies dieselfde beteken nie. Daarom is by Trente besluit dat kinders wat die gebruik van hulle redelike vermoëns nog ontbeer (usu rationis carentes) nie die misoffer sal ontvang nie (Denzinger 1957:329).

Die kindernagmaal, dit wil sê vir kinders vanaf hulle sesde jaar, is weer in die Rooms-Katolieke Kerk ingestel ook omdat die ouderdom waarop die gedoopte kind die confirmatio kon ontvang, al meer verlaag is. Omdat die viering van die mis en die deelname aan die altaarsakrament die hart van die Roomse gods- en kerkdiens is, is dit verstaanbaar dat hulle die kinders daaraan sal wil laat deelhê. Die prediking in die Rooms-Katolieke Kerk is nie veel meer as 'n soort voorbereiding vir die ontvang van die altaarsakrament nie. Volgens die Codex iuris canonici, 1983, can 913 word vereis dat kinders wat die mis wil ontvang: ".. voldoende kennis sal hê en sorgvuldig voorberei is ... sodat hulle in staat is om die Liggaam van die Heer met geloof en toewyding ..." te ontvang. Volgens can 914 is dit in die eerste plek die ouers se taak om toe te sien dat die kinders wat alreeds hulle redelike vermoens kan gebruik en behoorlik voorberei is, die misoffer sal ontvang. Dit beteken in die praktyk dat kinders van so 'n 6-7 jaar oud daarvoor kwalifiseer om die mis te ontvang.

Heussi (1949:76) oordeel dat die magies-sakramentele opvatting van die Nagmaal juis die basis verskaf vir die kindernagmaal. As die Nagmaal heilsnoodwendig is en verder ex opere operato funksioneer, dan kan dit die gedoopte kind ten goede kom om die misoffer te ontvang al is die kind se geloof en sy verstaan van die evangelie minimaal.

\section{OOR DIE TOELATING TOT DIE NAGMAAL BY CALVYN EN SOMMIGE VAN SY NAVOLGERS}

Die kerkhervorming het 'n enorme kerklike omwenteling in Wes-Europa teweeggebring. Met die beroep op die Heilige Skrif en die aanvaarding daarvan as die enigste maatstaf vir die leer en lewe van die gelowiges, is die kerklike lewe dramaties verander. Dit sal te ver voer om die veranderinge van en rondom die Nagmaal en die toelatingsvereistes vir 
deelname aan die Nagmaal tydens die Kerkhervorming volledig te bespreek. Hier word slegs kortliks na Calvyn se standpunte gekyk en dan na die opvattings wat in die Nederlandse Calvinistiese kerke gegeld het.

Die historiese argument kan begin met Calvyn se program vir die strukturering van die kerk wat hy in November 1536 aan die raad van Genève voorgelê het. In die program, Articles concernant I'organisation de l'église et du culte à Genève, proposes au Conseil par les Ministres, stel Calvyn dat geen kerk of gemeente behoorlik georganiseer is as daar nie 'n reelmatige viering van die Nagmaal is nie. Dit beteken ook dat niemand Nagmaal mag gebruik tensy dit gelowig en met eerbied vir die sakrament gedoen word nie. Dit is die uitgangspunt van Calvyn se beskouing oor die posisie van die Nagmaal in die kring van die gelowiges en wie tot die gebruik van die sakrament toegelaat kan word. As Calvyn dan verder argumenteer dan stel hy dat dit noodsaaklik is om die dissipline te handhaaf sodat die eerbaarheid van die kerk gehandhaaf kan word en dat die kinders van die gelowiges van jongs af in die leer van die kerk onderrig moet word sodat die suiwerheid van die leer gehandhaaf kan word. Die saak is van wesenlike belang want die Nagmaal is ingestel en bepaal sodat die gelowiges met hulle Hoof en Here en met mekaar verbind kan word. Daarom is dit nodig dat diegene wat 'n ergerlike lewe lei van die Nagmaal geweer moet word anders word die sakrament ontheilig en die eer van God aangetas. Calvyn cordeel dat as daar 'n werklike vrees vir die Here in die kerk bestaan, sal die dissipline gehandhaaf word en die onwaardiges van die Nagmaal geweer word.

Calvyn stel verder dat die kinders van die gelowiges onderrig moet word sodat hulle belydenis van hulle geloof in die teenwoordigheid van die gemeente kan aflê. Die kind kon, uit die aard van die saak, daardie belydenis nie by die doop aflê nie, daarom moet dit later gebeur. Die openbare belydenis van geloof is by Calvyn, net soos by die Vroee Kerk, 'n vaste voorwaarde vir die toelating tot die Nagmaal. Hierdie eis dat die kinders van die gelowiges belydenis van geloof moet aflê voordat hulle Nagmaal kan gebruik, is in die Calvinistiese hervorming die beginpunt en die aanleiding vir die kerklike kategese. Die kerklike kategese was op sy beurt weer 'n tipiese Reformatoriese verskynsel want voor die Kerkhervorming het Rome geen kategetiese stof vir die kinders gehad nie. Maar Calvyn oordeel dat alleen gelowiges Nagmaal mag gebruik. In sy 
Articles van 1537 stel hy dit so: "Want ons sien dat die Skrif nog altyd belydenis en geloof met mekaar verbind het, en die Skrif sê aan ons dat as ons werklik met die hart glo dan is dit reg dat ons met die mond behoort te bely oor daardie verlossing wat ons glo."

In Genève word dit 'n vaste gebruik dat elke kwartaal, voor die bediening van die Nagmaal, die kinders van die gemeente 'n geleentheid gegun is om belydenis van geloof af te lê nadat hulle in die gemeente ondervra is. Interessant genoeg word daar nie 'n presiese ouderdomsperk gestel nie. Oor die algemeen word aanvaar dat die kinders in hulle tienerjare was wanneer hulle belydenis van geloof afgelê het. Dit word bevestig as gelet word op die kwaliteit van die kategese handleidings wat in Genève gebruik is (Pont 1991:106-116).

Calvyn se opvattings blyk ook uit die Institutio (1559) IV.19.4 wanneer hy stel dat kinders aan die einde van hulle kinderjare en by die begin van hulle adolessensie oor hulle geloof rekenskap kan gee. Calvyn stel dan (IV.19.14):

'n Kind van tien jaar moet voor die kerk verskyn om belydenis van sy geloof af te lê. Hy moet oor elke hoofpunt van die godsdiens ondervra word en op elke hoofpunt moet hy antwoord. As hy iets nie weet of verstaan nie, moet hy verder daarin onderrig word. So moet hy met die kerk as getuie en ten aanskoue van die kerk die enige, ware en opregte geloof bely waarmee die gelowiges die enige God eendragtig dien.

Die feit dat Calvyn hier van 'n tienjarige kind praat, het nie beteken dat die kinders op tienjarige ouderdom al 'n volledige belydenis afgelê het nie. Dit het daarvan afgehang of die kind se beantwoording van die ondervraging bevredigend was. In hierdie verband is 'n opmerking van Spoelstra (1989:338-339) ter sake:

Vandag kan in die lig van die Empiriese Opvoedkunde vasgestel word dat 'n kind nie voor ouderdom 12 jaar tot abstrakte denke, begrip van en singewing aan leerstellings in staat is nie, 'n vermoe wat vir verantwoorde belydenis van die geloof nodig is om sin en betekenis aan die "gereformeende leer" toe te kan skrywe. 'n Mens kan veilig aanneem dat iemand ongeveer op skoolverlaat ouderdom of sekondêre skoolvlak in staat is om die leer te verstaan. 
Die Calvinistiese standpunt is van Genève af verder gedra. Die paar vaste rezls wat gegeld het, word in die verskillende kerkordes teruggevind. Die Geneefse Ordonnances Ecclesiastiques 1541-1561, artikel 77 het bepaal (Pont 1981:32).

Die Sondag voor die viering van die Nagmaal moet dit afgekondig word sodat geen kind soontoe sal kom voordat hy belydenis van geloof afgelê het, soos dit in die kategismus uiteengesit sal word .... Dit moet gebeur sodat niemand tot sy veroordeling die tafel van die Here sal nader nie.

Baie uitvoeriger word die prosedure uiteengesit in Marten Micron se Christlicke Ordinancien van 1554 wat in die Nederlandse vlugtelinggemeente van Londen gegeld het. Hier geld die uitgangspunt (Dankbaar 1956:82):

So laten wy dan gheen ander Duytschen totten ghebruyck des Nachtmaels toe, dan de ghene: die opentlick voer de gemeinte: oft voer de Dienaers ende Ouderlinghen der Ghemeinten, de belydenisse haers geloofs ghedaen ende haer der Christlicke straffen ghewillicklick onderworpen hebben.

Naas hierdie reël het 'n verdere reël in die Calvinistiese kerke gegeld wat deur die Franssprekende gemeentes in die suide van Nederland in 1563 so geformuleer is (Pont 1981:64): "Niemand sal by die Nagmaal ontvang word wat nie gekatkiseer is nie en wat nie geskik, sowel ten opsigte van lewenswyse as leer, bevind word nie."

By die Konvent van Wezel 1568 is geoordeel dat almal wat Nagmaal wil gebruik agt dae voor die gebeure hulle name aan die predikant sal voorlê sodat by hulle huisbesoek gedoen kan word. So kan dan vasgestel word of hulle "voorgaand leven" van so 'n kwaliteit was dat hulle Nagmaal kan gebruik. Hierdie praktyk is seker uit Genève afkomstig. Daar was die reêl dat 'n predikant en 'n ouderling voor die Nagmaal by elke huisgesin besoek sal aflê om vas te stel of die gelowiges se lewenstyl sodanig is dat hulle tot die Nagmaal toegelaat kan word. As maatstaf vir die ondersoek is die sonderegister in die Nagmaalsformulier gebruik (Pont 1981:86). 
Hierdie reêls is ook in die Nederlandse kerkordes opgeneem. Die laaste redaksie van hierdie kerklike reél was met die vasstel van die kerkorde van Dordrecht 1619 waar in artikel 61 gestel word:

Men zal niemand ten avondmaal des Heeren toelaten dan die naar de gewoonheid der kerk tot dewelke hij zich voegt, belijdenis der gereformeerde religie gedaan heeft, mitsgaders hebbende getuigenis eens vromen wandels, zonder welke ook degenen, die uit andere kerken komen, niet zullen toegelaten worden.

Die reëling verskil nie van artikel 54 van die kerkorde van 's-Gravenhage 1586 nie. Hierdie kerkorde was die geldende kerkorde vir die sinode van Suid-Holland waaronder die Kaapse gemeentes geressorteer het. So is die praktyk vir die toelating tot die Nagmaal ook in Suid-Afrika ingevoer. Wanneer in Nederland onder koning Willem I die Algemeen reglement van 1816 met die daarmee gepaardgaande reglemente ingevoer word, word die kerklike onderwys van die gedoopte kinders van die gelowiges behou. Maar dan word die hele saak van godsdiensonderwys dramaties gewysig. Tot in 1795, die jaar van die Franse omwenteling in Nederland, het die kinders godsdienisonderwys ontvang by die huis, in die skool en in die kerk. In 1798 het die owerheid egter bepaal dat onderwysers nie meer godsdiensonderwys mag gee nie aangesien die owerheid dan godsdienstig "neutraal" is. Daar word dan wel 'n opening geskep dat die predikant op skool aan die kinders wat hulle daarvoor aanmeld "leerstellige Godtsdienst" kan gee (Hooijer 1846:97).

In die kerk self is daar ook ' $n$ belangrike wysiging in die sin dat die kategese nie meer daarop gerig is om 'n verantwoorde "belydenis der Gereformeerde religie" af te le nie, maar om toegelaat te word tot die lidmaatskap van die Hervormde Kerk (Hooijer 1846:99). Die kategese loop dan uit op 'n openbare bevestiging van lidmate wat "plegtiglijk en met gepaste aanspraken" moet plaasvind (Hooijer 1846:106). Deel van die regte en voorregte van lidmaatskap van die gemeente is dat die lidmaat Nagmaal mag gebruik. So beteken lidmaat-word ook toelating tot die Nagmaal.

In die verbygaan kan daarop gewys word dat tot 1816 daar nie. 'n vaste formulier of selfs 'n vaste stel vrae is wat by die aflê van die openbare belydenis gebruik is nie. 
Die ondersoek en die stel van vrae het tot 1816 plaasgevind in die konsistoriekamer na afloop van die middagdiens. Die ondersoek is deur 'n predikant en 'n aantal ouderlinge hanteer (Lekkerkerker 1956:18-19). Eers deur middel van die reslings wat neergelê word deur die Algemeen Reglement 1816, word die openbare belydenis en die bevestiging tot lidmaat tydens 'n godsdiensoefening van die gemeente hanteer.

Hierdie praktyk word ook na Suid-Afrika oorgedra en wel deur die Algemeen Reglement van 1824 (Pont 1991:223). Daarvandaan word dit ook die patroon in ons kerk soos blyk uit die Kerkelyke Wetten en reglementen van 1857, arts 35-37. Hier word egter geen aanduiding gegee van die ouderdom van die kinders wat belydenis mag doen of van die inhoud van die kategese wat hulle moet ontvang nie. In die Wetten en Bepalingen voor de NHK in ZA van 1904 word in Hoofstuk III, artikel 10 bepaal dat deel van die kerkraad se dienswerk is: “... de afneming van de belijdenis des geloofs en bevestiging van nieuwe lidmaten in de gemeente." Vir die eerste maal word dan bepaal dat die ouderdom van die gedoopte kinders van die kerk 16 jaar vir die seuns en 15 jaar vir die dogters moet wees voor belydenis van geloof afgelê kan word. Die ouderdomme word in 1920 deur die Algemene Kerkvergadering verhoog na 17 en 16 en bly dan so totdat met die aanvaarding van die Kerkwet van 1950 die ouderdomsbepaling weer wegval. Daar word in Hoofstuk I, artikel 5 slegs gestel dat die kerkraad moet sorg vir die kategese, die afneem van die belydenis van geloof en die opneming van die kinders onder die belydende lidmate. Die verband tussen die afle van belydenis en die opname onder die belydende lidmate word ook in die Kerkorde, ordereęl 4.1.2.ii gehandhaaf ondanks die feit dat ordinansie 5.3.3 eerder van verantwoordelike as belydende lidmate praat.

As 'n oomblik hier stilgestaan kan word, dan kan gesê word dat die doop, ook die kinderdoop, die heenwysing is na die afwassing van die sonde deur die bloed van Christus en die deelgenootskap aan die liggaam van Christus. Deur die doop is die gedoopte 'n lidmaat van die gemeente-kerk, vergelyk ordereel 5.2.3. Lank voor die openbare aflê van die belydenis het die gedoopte gelowige reelmatig in die godsdiensoefening saam met die gemeente sy geloof bely by die aanhoor en nasê van die geloofsbelydenis.

By die aflê van die openbare belydenis na die kategese verkry die gedoopte gelowige toelating tot die Nagmaal. Eintlik het die gebeurtenis met lidmaatskap niks te 
make nie want die het die gedoopte gelowige verkry met die doop. Hier het die verenigingsreg wat in ons kerk begin geld het vanaf 1824 'n enkelvoudige saak kom bemoeilik deur die indruk te skep dat daar twee soorte lidmaatskap van die kerk kan bestaan. Maar miskien moet hierdie saak met 'n volgende geleentheid uitgepluis word. Hier is slegs belangrik dat die aflê van die geloofsbelydenis na kategese die hoofvoorwaarde is vir die toelating tot die Nagmaal. Daarby kom dan die vraag na die lewenskwaliteit van die gelowige.

So gesien blyk dit dat die voorwaardes vir die toelating tot die Nagmaal in die Calvinistiese kerklike wêreld feitlik dieselfde gebly het vandat Calvyn die voorwaardes in sy Articles van 1537 uitgespel het. Daarin het egter nou 'n verandering gekom. Die Algemene Sinode van die NG Kerk het in Oktober 1998 besluit: “... gedoopte kinders wat in Jesus Christus glo, aan die vereistes van 1 Kor 11 voldoen, en die begeerte het om Nagmaal te gebruik, tot die Nagmaal toegelaat mag word." Hierdie besluit kan in die gemeentes uitgevoer word “... wanneer die gemeentes daarvoor gereed is." Dit beteken dan dat kinders vanaf hulle eerste skooljaar in aanmerking kan kom vir toelating tot die Nagmaal.

Hierdie besluit van die Algemene Sinode het in ons kerk ook bepaalde nagevolge omdat, vanwex ons "oop uitnodiging" na die Nagmaal, dit nou kan gebeur dat kinders wat in die NG Kerk toegelaat word tot die Nagmaal by geleentheid in 'n Hervormde gemeente ook Nagmaal sou wil gebruik. Om die saak te kan beoordeel word 'n oomblik gekyk na die argumente ten gunste van die kindernagmaal.

\section{ENKELE ARGUMENTE WAT TEN GUNSTE VAN DIE KIN- DERNAGMAAL GEVOER WORD}

Dit is nogal belangrik om die argumente ten gunste van die kindernagmaal sorgvuldig te beluister. Die opvallende van hierdie argumente is dat een van die oudste voorwaardes wat gestel is vir toelating tot die Nagmaal heeltemal deur die voorstanders van die kindernagmaal verwerp of geignoreer word en dit is die vereiste van 'n suiwer gedrag, met ander woorde 'n gedrag in ooreenstemming met die vereistes van die Dekaloog. Waar die Reformatoriese Nagmaalsformuliere feitlik almal 'n uitvoerige sondelys het, word by die kindernagmaal byna gesuggereer dat soiets vir die kind nie nodig is nie! 
Afgesien van die weglating van hierdie vereiste, is dit interessant om te sien welke positiewe vereistes gestel word.

Die oudste argument ten gunste van die kindernagmaal is die wat in die RoomsKatolieke Kerk gevind word. Die uitgangspunt hier is dat die doop wat ex opere operato funksioneer, die dopeling reinig van die erfsonde en 'n character indelibilis aan die dopeling gee (Palmer 1957:124). Na die doop kan die dopeling nog net daadsondes verrig wat deur die gebruik van die ander sakramente uitgeboet kan word, soos deur die Lateraanse Konsilie van 1215, 1.41 bepaal is (Alberigo 1962:206). Dit word nog skerper geformuleer deur die Sinode van Florentina (Alberigo 1962:519) wat oor die doop leer: "Huius sacramenti effectus est remissio omnis culpe originalis et actualis omnis quoque pene, que pro ipsa culpa debetus ..." Hierdie gedoopte en dus in beginsel sondelose mens moet tot die sakrament van die Nagmaal toegelaat word want daar kan geen beletsel daarteen in die gedoopte self wees nie. Vandaar dat by Rome, vir 'n tydjie lank, die suigeling-Nagmaal moontlik was. Die sondelose dopeling kan mos nie as 'n onwaardige Nagmaalganger beskou word nie! Daarom bepaal Rome in die Corpus iuris canonici, can 913 dat gedoopte kinders wat Nagmaal wil ontvang “... voldoende kennis sal hê en sorgvuldig voorberei is ... sodat hulle instaat is om die Liggaam van die Here met geloof en toewyding ..." te ontvang. Die inisiatief moet van die kind uitgaan en daarvandaan moet die ouers toesien dat die kind sodanig toegerus is dat hy die misoffer kan ontvang.

Wat die ouderdom betref, word geoordeel dat kinders van 6-7 jarige ouderdom die misoffer kan ontvang. In die Roomse kerk is die kwaliteit van die ontvanger van die sakrament nie so belangrik nie want die werking van die sakrament word nie bepaal deur die geloof of die gesindheid van die ontvanger nie. Die sakraments-genade vloei vanself voort uit die sakrament (J Bernhart 1954:625).

Die argumente ten gunste van die kindemagmaal wat in die debat in die NG Kerk na vore gekom het, kan miskien soos volg saamgevat word:

- 'n Algemene stelling word gemaak dat daar in die Nuwe Testament geen aanduidings is of kinders Nagmaal gebruik het of nie. Die deelname van kinders aan die Nagmaal word ook nêrens in die Nuwe Testament expressis verbis verbied 
nie. Daarom word die afleiding gemaak dat niks in die Nuwe Testament die kindernagmaal verbied nie en daarom is dit aanvaarbaar.

- Die argument stel dat in die Ou-Testamentiese bedeling het die kinders aan die pasga deelgeneem (Eks 12:24-27). Dressel (1995:4-5) oordeel op grond daarvan dat kinders aan die Nagmaal moet kan deelneem.

- Hierby kom dan die argument dat die pasga en die Nagmaal beide verbondsmaaltye is. As lid van die verbond, op grond van sy doop, moet die kind Nagmaal kan gebruik. Prins (1998:5 \& 10) beklemtoon dit dat die gelowiges betrokke is by hulle verlossing en hulle lewe as kinders van God. Dit is, soos hy dit sien, die twee groot sake waarom die Nagmaal gaan. Hy stel dan:

Ons moet tot bekering kom. Ons moet die verlossing in Christus ontvang. Ons moet ons aan Hom toewy. Ons moet Hom met volharding volg. So ontvang elkeen wat die Nagmaal gebruik, daarmee saam God se seenninge .... Kinders wat die Nagmaal gebruik, moet weet wat dit beteken. Hulle moet ook die Here vir hulle verlossing kan dank en vir Hom kan sê dat hulle Hom liefhet.

- Dan word, met verwysing na 1 Korintiërs 11 gestel dat die waarskuwing ten opsigte van 'n onwaardige en onverskillige gebruik van die Nagmaal waarskynlik tot volwassenes gerig is. Aangesien hier egter geen ouderdomsbeperking gestel word nie, word aanvaar dat hierdie waarskuwing nie die kind se toegang tot die Nagmaal kan versper nie.

- 'n Interessante argument word gevoer na aanleiding van Vraag en Antwoord 81 van die Heidelbergse Kategismus. Dressel (1995:4) is van mening dat hier kennis van die betekenis van die Nagmaal veronderstel word. Dit sou dan nie die kind uitsluit nie. Ten opsigte van Vraag en Antwoord 65, 66 en 75 is die argument dat die Nagmaal gegee is sodat die gelowige die evangelie beter kan verstaan en sodat sy geloof versterk word. Ook die stellings sluit die kind nie uit nie aangesien hy ook die versterking van sy geloof nodig het. 
Dan stel Dressel (1995:4):

Die Nagmaal vervul 'n waardevolle opvoedingsfunksie. Juis die Nagmaal kan daartoe dien dat ook die troosryke betekenis van die doop ... beter verstaan word. Die feeste in die Ou Testament het 'n belangrike funksie vervul in die verbondsopvoeding van die kinders.

Met verwysing na die kinderdoop word ook geargumenteer dat die kind daar die sakrament ontvang terwyl hy volkome onbewus daarvan is. Net so kan die kind glo dan die Nagmaal ontvang om dan later, soos met die doop, te verstaan en te glo (Notule Alg Sinode NG Kerk 1998:117). Dit wil, terloops, tog voorkom dat hierdie argument direk teenstrydig is met die argument wat net hierbo genoem is.

Ten slotte is daar nog die sosiologiese argument. Daarin word gestel dat die kind tot die Nagmaal toegelaat moet word "... omdat [die Nagmaal] 'n sterk aksent lê op die gesinsband en ons-saam-belewing van die godsdiens." Die kind sal deur die gebruik van die Nagmaal ook aan die gemeente gebind word (Notule Alg Sinode NG Kerk 1998:117). Die sosiologiese argument pleit terselfdertyd dat die grense van die kerklike strukture meer deursigtig moet wees. Die betoog is dat die verbond wyer is as die amptelike lidmaatskap van die kerklike strukturur (Dingemans s a:207-220). Daarom word gestel dat indien iemand Nagmaal wil gebruik, die enigste vraag wat gevra mag word is of die persoon die behoefte daaraan het om Nagmaal te gebruik of om deel te hê aan wat die gemeente uitdeel. Interessant is dat die Skriftuurlike voorwaardes vir die toelating tot die Nagmaal hier nie meer tel nie.

Dressel (1995:17) stel in hierdie verband dat die spesifieke behoeftes waaraan die kindermagmaal moet voldoen is:

... die noodsaaklikheid dat die kind moet beleef dat hy ten volle deel van die geloofsgemeenskap is. Dit hang in die besonder ook saam met die kind se behoefte aan geborgenheid en die behoefte om te voel dat hy 'behoort aan.' [Ten tweede], die feit dat ' $n$ kind se geloofslewe deur wat hy hier beleef en doen, gevorm word, en [ten derde], die noodsaaklikheid dat die kind ook in die gemeentelike betrokkenheid die eenheid van die gesinsband moet beleef. 
Hierdie samevatting van die sewe belangrikste argumente wat ten gunste van die kinderNagmaal in die NG Kerk gevoer is, kan 'n oomblik van naderby besien word. Die oorheersende indruk is egter dat ons hier te make het met 'n voorbeeld van die nuwe teologie. Die verskuiwing is in 1994 al so onder woorde gebring (Burden 1994:114):

\begin{abstract}
Hierdie nuwe siening is die gevolg van 'n paradigma-verandering: waar teologie 'n normatiewe van-bo-na-onder bedryf was, word dit nou 'n vanonder-na-bo handeling. Ons sou kan sê daar vind 'n "demokratisering" van "teologie" plaas wat die massas bevry van die oorheersing van die klerikale elite en hulle bekragtig ... met hulle "gereformeerde geboortereg," die amp van alle gelowiges.
\end{abstract}

Dit is 'n baie interessante uiteensetting wat daarop dui dat met hierdie soort van denke daar tot op die rand van die teologie gevorder word. Juis soos hier in die argumentering oor die kindernagmaal ook blyk, is alleen die behoefte en die aansprake van die mens ter sake. Dan is daar nie meer sprake van teologie nie.

\title{
5. ENKELE OPMERKINGS
}

Dit is seker die moeite werd om in hierdie verband weer te luister na Calvyn. Dit is buitendien hoofsaaklik sy Bybelse teologie wat sowel in die kerk se belydenisskrifte as Nagmaalsformulier teruggevind word. Calvyn laat hom in die Institutio IV.16.30 oor die toelating van kinders tot die Nagmaal uit. Dit in hoofsaak omdat Servet, in 'n aanval op Calvyn, die mening uitspreek dat die kinderdoop logies tot die kindernagmaal moet lei. In sy antwoord stel Calvyn dan:

So ver dit die doop aangaan, maak die Here daarin trouens geen ouderdomsonderskeid nie. Maar Hy bied nie die Nagmaal aan sodat almal daaraan deel moet hê nie, maar sodat slegs diegene wat bekwaam is om die liggaam en bloed van die Here te onderskei, in staat is om hulle gewetens te ondersoek, die dood van die Here te verkondig en oor die krag daarvan na te dink. ... As slegs diegene wat weet hoe om die heiligheid van die liggaam van Christus na behore te onderskei, in staat is om op waardige wyse daarvan te eet, waarom sou ons dan vir teer kindertjies gif aanbied as lewendmakende voedsel? ... Die 
pasga, in die plek waarvan die Nagmaal nou gekom het, het nie somaar enigiemand sonder onderskeid as gaste toegelaat nie Dit is egter na behore gecet deur diegene wat op grond van hulle ouderdom oor die betekenis daarvan navraag kon doen.

Die opvallende van hierdie argument is dat Calvyn uitgaan van die standpunt dat die Nagmaal 'n gawe van die lewende God aan die mens is. Dit beteken dat God die voorwaardes vir die ontvangs van die Nagmaal vasstel en dat die gelowige wat die Nagmaal wil ontvang daaraan moet voldoen. Daardie voorwaardes kan uit die Woord van God, die Bybel, nagelees word sodat die gelowige dit kan gehoorsaam. Om daardie voorwaardes in die geloofsgemeenskap wat die kerk is te laat geld, het Calvyn die dienswerk van die ouderling ingestel wat by sy bevestiging in die amp die opdrag ontvang om "... noulettend toe te sien dat elkeen hom in belydenis en lewe betaamlik gedra, die onordelikes te vermaan en sover moontlik te verhoed dat die sakramente ontheilig word." Die sakramente as gawes van God aan sy gemeente is nie sondermeer vir almal toeganklik nie en omdat die sakramente 'n heenwysing is na die hart van die Christelike godsdiens en omdat dit die ontmoeting met God, die verlossing van die sondaarmens vanwee Christus se kruisoffer versinnebeeld, is dit van die pêrels wat die gemeente sorgsaam in hulle hande moet hou, vergelyk Matteus 7:6. Daarom moet die gelowige voordat hy na die Nagmaal kan gaan, homself eers beproef (1 Kor 11:28-29) en op grond van vers 27 is dit die ouderling se taak om die onwaardiges van die Nagmaal te weerhou. Dit is nie vreemd nie want waar Rome die bieg en absolusie vereis as 'n voorwaarde om die mis te ontvang het Calvyn die voorbereidingsdiens vir die gemeente, die selfondersoek deur die gelowige en die opdrag aan die ouderling om toe te sien dat die sakrament nie ontheilig word nie na vore gebring. Hierdie versigtigheid rondom die sakrament het sy oorsprong waarskynlik in die opdrag om die lewende God met ontsag en vrees te dien (vergelyk Ps 2:11; Ps 86:11; Ps 111:10; Spr 9:10; 2 Kor 7:1; Hand 5:111) en in gedagte te hou dat die mens 'n sondaar is en bly.

Daarom is die waarskuwing dat die Nagmaal nie op 'n ongepaste manier, onwaardig, onverskillig of roekeloos gebruik sal word nie, so emstig opgevat. Dit is opvallend dat juis hierdie aspek van die Nagmaalsviering die aanleiding is vir die kategese van die kinders en die vereiste dat die gelowige Nagmaalganger oor die gawe 
van die onderskeid moet beskik. Hier is dit nogal interessant om die sonderegisters van die Calvinistiese Nagmaalsformuliere na te gaan om vas te stel hoe ernstig hierdie hele saak bejeên word.

Hier kom dan nog 'n verder oorweging by. In die kerke van die Calvinisme gaan dit by die Nagmaal om die ontvangs van die Nagmaalselemente in die geloof, soos dit deur die sursum corda uitgedruk word. Dit is 'n verdere rede vir die kategese want alleen na belydenis van geloof kan die Nagmaalganger soos en saam met die gemeente glo.

As dit gestel word, is dit seker belangrik om te onthou dat Calvyn besig was om die kerk te bou en om dit te kan doen, moes hy 'n kerklike teologie ontwikkel. Wat dit inhou, word gou duidelik as gelet word op die kategismus wat Calvyn opstel vir die gedoopte kinders van die gemeente wat belydenis van geloof wil aflê (Peter 1965:171205). Daarby oordeel Calvyn dat die gaan na die Nagmaalstafel nie net berus op die eie beslissing en verantwoordelikheid van die gelowige nie. Daarom is die Nagmaal van die begin af ook kerkordelik gereęl onder die opsig van die kerkraad.

Dat die toegang tot die Nagmaal kerkordelik gereël is, was vanselfsprekend nie net 'n aspek van die Calvinistiese hervorming nie. Ook in die Lutherse kerk moes die gedoopte kinders van die kerk eers belydenis van geloof aflê voor hulle tot die Nagmaal toegelaat is. Daarby moes die gelowiges voor die Nagmaal hulleself by die predikant aanmeld wat moes oordeel of hulle tot die Nagmaal toegelaat kan word (Sehling 1965:435-7). Daar is by die voorbereidingsdiens vasgestel wie nie die Nagmaal mag bywoon nie!

Saamgevat kan gestel word vier oorwegings van oudsher af die toelating tot die Nagmaal bepaal het. Dit is dan:

- Die selfstandigheid van die kerklike dissipline wat beteken dat die opsig en tug oor die gelowiges in die eerste plek deur die kerkraad uitgeoefen word.

- Die openbare aflegging van geloof of instemming met die geloofsbelydenis van die kerk. Dit is die eindpunt van 'n kerklike kategese wat daarop gemik was dat die gedoopte kind uit die gemeente die inhoud van die leer van die kerk sal begryp en tot sy eie kan maak. Dit het beteken dat kinders in hulle tienerjare was wat 
toegelaat is om belydenis van geloof af te lê. Die aflè van die openbare geloofsbelydenis het nie altyd die lidmaatskap van die gelowige verder bepaal nie.

- Die beklemtoning dat die geloofsbelydenis en die sakrament (as verbum visibile) ' $n$ belangrike sentrum in die lewe van die gemeente is. Dit gaan hiermee om die heiligheid van die gemeente wat homself heilig, dit wil sê dit gaan om 'n gemeente wat as 'n lewende liggaam in die geloof opgebou word (Ef 4).

- Die voordurende lewenswandel van die gelowiges wat Nagmaal wil gebruik, word ook beoordeel omdat leer en lewe in mekaar se verlengde lê. Vandaar dat die lewenswandel van die gelowiges voortdurend beoordeel word om juis so die heiligheid van die gemeente heilig te hou.

As dit die maatstaf vir die toelating tot die Nagmaal is soos dit uit die Skrif, die Calvinistiese teologie en die voortdurende gewoonte afgelei kan word, dan kan die volgende opmerkings gemaak word oor die redes wat aangevoer is in die NG Kerk waarom 6-7 jarige kinders tot die Nagmaal toegelaat moet of kan word.

- Die argument dat die kindernagmaal aanvaarbaar is omdat die Nuwe. Testament dit nie uitdruklik verbied nie, gaan beslis nie op nie. Dit skep die indruk dat eers op die instelling van die kindernagmaal besluit is en dat daarna gesoek is na Skriftuurlike gegewens wat dit verbied. Toe dit nie gevind kan word nie, word die gevolgtrekking gemaak dat dit aanvaarbaar is.

Die gegewens rondom die instelling van die Nagmaal, waar geen kinders aanwesig was nie, en die beskrywing van die Jerusalemse gemeente in Hand 2 en die voorwaardes wat uitgespel word in 1 Kor 11 gee nie die indruk dat dit 'n gebruik in die vroegste kerk was om 6-7 jarige kinders tot die Nagmaal toe te laat nie. Die posisie wat die kind in die kultururmilieu van daardie dae beklee het, maak dit onwaarskynlik dat die kind al deel van die Nagmaalgemeenskap was.

- Die argument dat die kinders van die gelowiges in die Ou-Testamentiese bedeling aan die pasga deelgeneem het, en daarom in die Nuwe Testament aan die Nagmaal behoort deel te hê, lyk nie na 'n dwingende argument nie. Die instellingsgebeure van die Nagmaal weerspreek dit in ieder geval dat die Nagmaal as 'n 
herhaling van die pasga gesien kan word. 'n Vergelyking van die Nagmaal in die Vroeẽ Kerk en die pasga dui ook daarop dat hierdie argument nie werklik aanvaar kan word nie.

- Dit word nie betwis dat die Nagmaal 'n verbondsmaaltyd is nie. Maar dit hoef nie te beteken dat die gedoopte kind daarom 'n reg op deelname aan die Nagmaal het voordat hy nie voldoen het aan die vereistes wat nog altyd vir deelname aan die Nagmaal gegeld het. Dit is nie korrek om 'n dwingende eis te stel dat die twee sakramente, doop en Nagmaal, in alles parallel moet wees nie. Dit word nêrens in die Bybel so gestel of vereis nie en kan ook nie uit die Skriftuurlike gegewens afgelei word nie.

Dit is verder 'n oop vraag as Nagmaal beskikbaar gestel word aan sesjarige kinders of daar nog werklik sprake van 'n Nagmaalsviering kan wees omdat dan die voorwaardes wat nog altyd vir toetrede tot die Nagmaal eerbiedig is, oorboord gegooi word.

Die vereiste dat die Nagmaal op 'n waardige wyse gebruik moet word en dat elkeen wat dit ontvang homself moet beproef is deur die eeue deur die kerk gehandhaaf en op 'n bepaalde manier verstaan. Daarby kom dat die kerk deur die eeue op 'n besondere manier erns gemaak het met die feit dat die Nagmaal vir die gelowiges alleen bedoel is. As dit alles met 'n paar oppervlakkige argumente negeer word, dan wil dit voorkom dat die toelating van sesjarige kinders tot die Nagmaal 'n dwaling is.

As gelet word op die minimum geloofskennis wat van die Nagmaalganger vereis word sodat almal soos die kerk en saam met die kerk glo en dat almal kan begryp wat die verkondiging van die Nagmaalsakrament is, dan is dit duidelik dat die toelating van sesjarige kinders tot die Nagmaal 'n misvatting is.

Dit is 'n merkwaardige argument wat gevoer word dat die kind terwille van sy opvoeding Nagmaal moet kan gebruik. Dit moet toegegee word dat Calvyn 'n sterk didaktiese element in die Nagmaalsviering invoeg deur middel van die verklarende Nagmaalsformulier, maar dan gaan dit om iets anders as om die algemene opvoeding van die kinders. 
Die argument wat hier gevoer word dat die kind maar Nagmaal kan gebruik sonder dat hy begryp waaroor dit gaan, lyk asof dit juis 'n oortreding kan wees van die waarskuwing dat die Nagmaal nie op 'n onwaardig wyse gebruik mag word nie.

Die sosiologiese argument wat pleit vir die kindernagmaal kom nie ooreen met die kind-beeld wat in Deuteronomium 6 gevind word nie. In Deut word dit duidelik dat die kind nie 'n volwassene is met net min lewensjare nie. Hy is nog kind, 'n mens wat nog nie werklik keuses kan maak nie (Deut 6:20), 'n onvolwassene wat nog onderrig moet word (Deut 6:7). Daarom is die kategese wat vir die gedoopte kind vooraf moet gaan aan sy toelating tot die Nagmaal nie 'n vreemde saak nie. Dit is veel eerder die raamwerk van die Skrif-voorbeeld wat as noodsaaklik en aanvaarbaar beskou moet word.

\section{AFSLUITENDE OPMERKINGS}

Met hierdie oorsig oor die saak van die toelating van 6-7 jarige kinders tot die Nagmaal het dit opgeval dat die argumente wat aangevoer is om die saak te regverdig nie juis sterk staan nie. Die sosiologiese argument en die humanistiese behoefte behoort nie swaarder te weeg as die Skriftuurlike gegewens en die kerk se voortdurende gewoonte nie.

Die vraag ontstaan nou dat die Algemene Sinode van die NG Kerk die kinderNagmaal aanvaar het, of die besluit nie die eenheid-in-die-geloof versteur het nie. Dit wil voorkom dat die aanvaarding van die kindernagmaal nie op deugdelike teologiese gronde berus nie en daarom nie aanvaarbaar geag kan word nie. Dit kan beteken dat die Nagmaalsgemeenskap tussen die NG Kerk en die Hervormde Kerk daarmee problematies word.

Die Nagmaal is en bly ' $n$ besondere gebeurtenis in die lewe van die gemeente want dit is nog steeds verbum visibile wat aan ons die Evangelie oordra dat Jesus Christus Hom terwille van ons opgeoffer het, dit bly ' $n$ teken en ' $n$ seel wat God gegee het sodat ons die Evangelie reg sal verstaan. Maar dan moet ons dit gebruik vir die doel waarvoor die Here God dit aan sy verbondsvolk geskenk het. Dit moet ons sorgvuldig oorweeg want ons is afhanklikes wat nie straffeloos met God se genadegawes kan maak wat ons wil nie. 


\section{Literatuurverwysings}

Alberigo, J et al 1962. Conciliorum Oecumenicorum Decreta. Basel e a: Herder.

Bernhart, J (Hrsg) 1954. Thomas von Aquino Summe der Theologie. Stuttgart: Alfred Kröner Verlag.

Bethune-Baker, J F 1958. An Introduction to the early history of Christian Doctrine. London: Metheun \& Co Ltd.

Burden, J J 1994. Teologiese opleiding in Suid-Afrika: 'n Toekomsblik. HTS 50(1\&2), 111-139.

Codex Iuris Canonici 1983. London: Collins.

Dankbaar, W F (red) 1956. Marten Micron: De christlicke Ordinancien der Nederlantscher Ghemeinten te Londen (1954). 's-Gravenhage: Martinus Nijhoff.

Denzinger, H 1957. Enchiridion symbolorum. Romae et al: Herder.

Dressel L C 1995. Kinders aan die Nagmaalstafel: 'n Teologiese besinning. Bloemfontein: EVTO-UOVS.

Harnack, A 1909. Lehrbuch der Dogmengeschichte. Tübingen: J C B Mohr.

Heussi, K 1949. Kompendium der Kirchengeschichte. Tubingen: J C B Mohr.

Hooijer, C 1846. Kerkelijke Wetten voor de Hervormden in het Koningrijk der Nederlanden. Zaltbommel: John Noman \& Zoon.

Jungman, J A 1959. The early liturgy. London: Longman \& Todd.

Lekkerkerker, A F N 1956. Kantteekeningen bij het Hervormd Dienstboek III. s'Gravenhage: Boekencentrum NV.

Palmer, P F 1954. Sacraments and worship. London: Longmans, Green \& Co.

Pont, A D 1981. Die historiese agtergronde van ons kerklike reg, I. Pretoria: HAUM.

Pont A D 1991. Die historiese agtergronde van ons kerklike reg, II. Pretoria: Kital.

Pont, A D 1991. Confession of faith in Calvin's Geneva, in Van 't Spijker, W, Calvin: Erbe und Auftrag, 106-116. Kampen: Kok Pharos.

Sehling, E 1965. Die evangelischen Kirchenordnungen des xvi Jahrhunderts. Hessen: Die gemeinsamen Ordnungen. Tubingen: J C B Mohr (Paul Siebeck). Spoelstra, B 1989. Gereformeerde Kerkreg en Kerkregering: Hammanskraal: HTS. 